\title{
Experimental investigation of surface roughness, flank wear, chip morphology and cost estimation during machining of hardened AISI 4340 steel with coated carbide insert
}

Sudhansu Ranjan Das ${ }^{1 *}$, Asutosh Panda ${ }^{2}$ and Debabrata Dhupal ${ }^{2}$

\begin{abstract}
Background: Now-a-days, newer hardened steel materials are coming rapidly into the market due to its wide applications in various fields of engineering. So the machinability investigation of these steel materials is one of the prime concern for practicing engineers, prior to actual machining.

Methods: The present study addresses surface roughness, flank wear and chip morphology during dry hard turning of AISI 4340 steel (49 HRC) using CVD (TiN/TiCN/Al $\mathrm{O}_{3} / \mathrm{TiN}$ ) multilayer coated carbide tool. Three factors (cutting speed, feed and depth of cut) and three-level factorial experiment designs with Taguchi's $\mathrm{L}_{9}$ Orthogonal array (OA) and statistical analysis of variance (ANOVA) were performed to investigate the consequent effect of these cutting parameters on the tool and workpiece in terms of flank wear and surface roughness. For better understanding of the cutting process, surface topography of machined workpieces, wear mechanisms of worn coated carbide tool and chip morphology of generated chips were observed by scanning electron microscope (SEM). Consequently, multiple regression analysis was adopted to develop mathematical model for each response, along with various diagnostic tests were performed to check the validity and efficacy of the proposed model. Finally, to justify the economical feasibility of coated carbide tool in hard turning application, a cost analysis was performed based on Gilbert's approach by evaluating the tool life under optimized cutting condition (suggested by response optimization technique).

Results: The results shows that surface roughness and flank wear are statistically significant influenced by feed and cutting speed. In fact, increase in cutting speed resulted in better surface finish as well as increase in flank wear. Tool wear describes the gradual failure of cutting tool, caused grooves by abrasion due to rubbing effect of flank land with hard particles in the machined surface and high cutting temperature. Chip morphology confirms the formation of saw-tooth type of chip with severity of chip serration due to cyclic crack propagation caused by plastic deformation. The total machining cost per part is found to be $\$ 0.13$ (i.e. in Indian rupees Rs. 8.21) for machining of hardened AISI 4340 steel with coated carbide tool.

Conclusions: From the study, the effectiveness and potential of multilayer TiN/TiCN/Al $\mathrm{O}_{3} / \mathrm{TiN}$ coated carbide tool for hard turning process during dry cutting condition possesses high yielding and cost-effective benefit to substitute the traditional cylindrical grinding operation. Apart, it also contributes reasonable option to costlier CBN and ceramic tools.
\end{abstract}

Keywords: Hard turning, Surface roughness, Flank wear, Chip morphology, ANOVA, Cost analysis

\footnotetext{
* Correspondence: das.sudhansu83@gmail.com

'Department of Mechanical Engineering, JK Lakshmipat University, Jaipur

302026, Rajasthan, India

Full list of author information is available at the end of the article
} 


\section{Background}

Now-a-days due to growing demand of high precision components to attain peak performances, hardened steels with hardness above $45 \mathrm{HRC}$ have numerous applications in automotive gear, machine tool and die industry because of their superior characteristics (high thermal stability, high indentation resistance, high abrasiveness, low ductility and high value of hardness to modulus of elasticity ratio).

In hard turning, high hardness of workpieces, significant cutting forces and high temperatures at the workpiececutting tool interface indicate strict necessity for tool rigidity and tool wear resistance. Normally these conditions give rise to the damage of the interact surfaces (tool-chip and workpiece-tool); as a reaction, the geometrical and dimensional precision are decreased or altered and more the material mechanical characteristics are changed (Bouacha \& Terrab 2016). Therefore not only force and temperature distribution in the cutting zone are of great importance, but the study of surface roughness, tool wear and chip formation are also required for the betterment of productivity, the improvement of quality of the machined products and the establishment of a techno-economical and environmental friendly machining process.

Several experimental studies have been performed to investigate the influence of cutting parameters (cutting speed, feed and depth of cut), machining time, tool geometry, workpiece hardness, tool materials, different coatings on machinability characteristics like surface roughness, cutting forces and tool flank wear with various workpiece materials (MDN 250, AISI 4340, 4140, 52100, 6150, D2, D3, H10, $\mathrm{H} 11$ and $\mathrm{H} 13$ die steel) in hard turning for process optimization and machining performance prediction through experimental methods (Tamizharasan et al. 2006; Lalwani et al. 2008; Hosseini et al. 2016; Das et al. 2016), mathematical models (Singh \& Rao 2007; Al-Ahmari 2007; Ozel et al. 2007; Sieben et al. 2010; Asiltürk \& Çunkaş 2011) and statistical analysis (Davim \& Figueira 2007; Caydas 2010; Bouacha et al. 2010; Nabil et al. 2012).

Aslan et al. (2007) conducted an optimization study by machining a hardened AISI 4140 grade (63 HRC) steel with $\mathrm{Al}_{2} \mathrm{O}_{3}+\mathrm{TiCN}$ mixed ceramic inserts in order to analyze the effect of cutting parameters (cutting speed, feed rate and depth of cut) on surface roughness and flank wear by employing Taguchi technique, ANOVA and regression analysis. Their results showed the flank wear (VB) value decreased as the cutting speed and the depth of cut increased; however, it first decreased and then increased as the feed rate increased. For the same material, Asiltürk and Akkus (2011) determined the effect of cutting parameters on surface roughness using experimental (Taguchi's OA) and statistical (ANOVA) techniques. Results proved that the most significant parameter affecting surface roughness is feed rate. However, other machinability characteristics like tool wear, cutting force and chip morphology have not been considered for study which is essential for hard turning. The work of Davim and Figueira (2007), concerning the machinability evaluation of cold-work tool steel (D2) using statistical techniques, presented that with an appropriate choice of cutting parameters it is possible to obtain a surface roughness with $\mathrm{Ra}<0.8 \mu \mathrm{m}$. This implies that hard machining is an alternative competitive process, which allows eliminating cylindrical grinding operation solutions. During machining of hardened AISI D3 steel with coated carbide tool, the RSM and Taguchi methods were utilized for the optimization of surface roughness as well as tool wear and the optimization results provided by both techniques are in close proximity by Dureja et al. (2014). According to parametric analysis ANOVA, feed and cutting speed were the significant factors influencing flank wear and the factor significantly affecting surface roughness is feed. During finish turning hardened AISI H13 steel (55 HRC) with PVD-TiN coated ceramic inserts, Suresh and Basavarajappa (2014) revealed that (1) tool wear was highly significant influenced by cutting speed followed by feed, accelerating abrasion marks on tool's flank face (2) surface finish was improved as cutting speed increased and deteriorated with feed, and (3) formation of serrated saw-tooth chips occurred due to increase of cutting speed and feed. Later, using similar tool material, Das et al. (2015) studied flank wear and surface roughness during machining of hardened AISI 4140 steel (52 HRC) and showed that feed followed by cutting speed and cutting speed-depth of cut significantly affected surface roughness; whereas cutting speed had the largest influence on flank wear. Additionally, their results highlight the cost estimation based on Gilbert's approach of economics in machining to vindicate the economical viability of coated ceramic tool in hard turning process.

Aouici et al. (2011a) have applied ANOVA and RSM to examine the effects of machining parameters including cutting speed, feed and machining time for modeling and optimization of surface roughness and flank wear in hard turning of AISI H11 (X38CrMoV5-1) steel with CBN tool. Conclusions showed that flank wear is predominantly controlled by machining time followed by cutting speed, while feed in case of surface roughness. Similarly, Gaitonde et al. (2009) explored the consequences of machining parameters $(\mathrm{v}, \mathrm{f}, \mathrm{t})$ on various machining responses in view of hard turning as a potential alternative to costly grinding operations. Results of their experimental analysis concluded that tool wear is highly sensitive to cutting speed, machining time and feed. The combination of low feed rate, less machining time, and high cutting speed was necessary for minimizing the surface roughness. The same conclusion was made by Suresh et al. (2012) during machinability investigation of hardened AISI 4340 steel in hard turning with coated carbide insert.

Recently, Senthilkumar et al. (2014) experimentally investigated the performance of cemented carbide inserts in terms of flank wear and surface roughness by 
assessing the effect of cutting parameters ( $v, f, d)$ and tool geometries (insert shape, relief angle and nose radius) and optimized using Taguchi based grey relational analysis in turning practically used automobile wheel axle materials of Ambassador car (512 BHN), Standard jeep (448 BHN), Ashok Leylank truck (522 BHN), based on the experiments designed using Taguchi's Design of Experiments (DoE). Analysis of variance shows that cutting insert shape is the prominent parameter followed by feed rate and depth of cut that contributes towards output responses. Meddour et al. (2015) have studied the effects of cutting parameters and tool nose radius on cutting forces and surface roughness evolution during hard turning of AISI 52100 steel by ceramic tool. The study showed that, lower depth of cut with nose radius gives higher surface roughness due to material side flow and also, they suggested to cut with large nose radius for lower feed rates for better surface finish. An experimental investigation on machinability evaluation of Hadfield steel by Horng et al. (2008), developed the RSM model using the CCD in the hard turning which uses uncoated $\mathrm{Al}_{2} \mathrm{O}_{3} / \mathrm{TiC}$ mixed ceramic tool for flank wear and surface roughness. Results indicated that the flank wear was influenced principally by cutting speed (43\%) and marginally by interaction effect of nose radius of tool with feed (12.84\%). The surface roughness is influenced significantly by nose radius (43.18\%) and cutting speed (29.67\%). Saini et al. (2012) presented that surface roughness is vitally affected by feed and nose radius, serving as when feed inflates surface roughness maximizes but subsides with increase in nose radius. Apart, tool wear becomes predominant when cutting speed increases succeeded by nose radius.

Aouici et al. used CBN tool in machining AISI H11 steel encompasses a relatively wide range of workpiece hardness values (40, 45 and 50) HRC and adopted statistical methodology to examine the inference of cutting parameters and workpiece hardness on the surface roughness and on additional responses such as cutting forces. They used response surface methodology (RSM) in order to develop empirical model for the prediction of output responses. Results incredibly showed the principal effect of exogenous variables: depth of cut and workpiece hardness on cutting force components. However, both feed rate and workpiece hardness has statistical significance on surface roughness. In addition, work performance of multi-layer CVD coated carbide tool in terms of cutting forces, surface roughness and tool life during turning of hardened AISI 4340 steel was investigated by Chinchanikar \& Choudhury (2013a). However, they observed surface roughness gets affected remarkably at higher feed $(0.15 \mathrm{~mm} / \mathrm{rev})$ and depth of cut $(1 \mathrm{~mm})$ coupled with higher cutting speed, more prominent in case of softer work piece (35 HRC). Also, their study of analysis concluded that lower cutting forces are employed for PVD coated tools attributes positive cutting edge in comparison to negative, stable cutting edge style CVD coated tool. In another study, acknowledged by Dureja et al. (2010) showed surface roughness significantly revamps using machining parameters such as feed, workpiece hardness and cutting speed while flank wear is realized under the effect of cutting speed and feed which are found the most significant during finish turning of hardened AISI H11 steel with CBN tools.

Aneiro et al. (2008) investigated the influence of cutting parameters on tool wear, cutting forces, and surface roughness during turning of hardened steel using coated carbide and PCBN tools, respectively. The results concluded that machining of medium hardened steels was productive with coated carbide tools. Tool life observed was particularly long for the coated carbide with relatively low flank wear. However, it was about half of the tool life of PCBN tool at similar cutting conditions, but, claimed that hard machining with coated carbides is justified as PCBN tool prices are, probably, more than twice that of coated carbide price. Sahoo and Sahoo (2012) experimentally investigated the machinability of hardened AISI 4340 steel and compared the performance of uncoated and multilayer $\left(\mathrm{TiN} / \mathrm{TiCN} / \mathrm{Al}_{2} \mathrm{O}_{3} /\right.$ $\mathrm{ZrCN}$ and $\mathrm{TiN} / \mathrm{TiCN} / \mathrm{Al}_{2} \mathrm{O}_{3} / \mathrm{TiN}$ ) coated carbide inserts in finish hard turning. Experimental results revealed that multilayer TiN coated insert performed better than uncoated and $\mathrm{ZrCN}$ coated carbide insert in terms of flank wear and surface roughness. The savings in machining costs using TiN coated insert is $93.4 \%$ compared to uncoated carbide and $40 \%$ to $\mathrm{ZrCN}$ coated carbide inserts respectively. Cakir et al. (2009) developed mathematical models (linear, quadratic and exponential) for modeling and assessing the influence of coating materials (CVD-TiN, PVD-TiAlN) and cutting parameters on surface roughness while turning of cold work steel. They concluded that among all the models, the quadratic model is suitable to predict the surface roughness. Although the positive effect of higher cutting speeds was noticed when employing CVD coated $\left(\mathrm{TiCN}+\mathrm{Al}_{2} \mathrm{O}_{3}+\right.$ TiN) insert, lower surface roughness are obtained when employing PVD coated (TiAlN) insert. Authors suggested that in view of the dissimilar behaviors of the two different coated inserts against cutting speed, another study would be required concerning the tool life.

Although, sufficient work has been reported on machinability of hardened AISI 4340 steel (Caydas 2010; Suresh et al. 2012; Sahoo \& Sahoo 2012; Chinchanikar \& Choudhury 2013b; Pal et al. 2014) during turning, machining performance in terms of tool wear, surface roughness, chip morphology and cost analysis combination during hard turning with coated carbide tool is rarely reported. As can be seen from the literature reviews, cutting performance of ceramic and CBN tool materials has been extensively assessed in this field and observed to be acceptable because of longer tool life. However, their cost is very high as compared to 
carbides. Yet little studies have been conducted related to cost analysis in hard turning of AISI 4340 steel using coated carbide insert in order to verify its economical feasibility and cutting performance. Furthermore, most of the literatures have focused on assessment, modelling and optimization for surface roughness and tool wear but almost no or little research work has been yet reported on machined surface morphology, mechanism of tool wear, chip morphology and economical feasibility which need to be explored for better understanding of the process in order to improve the overall productivity in manufacturing by hard turning operation from technological, ecological and economical point of views.

The current experimental work is to investigate the influence of cutting parameters (cutting speed, feed and depth of cut) on surface roughness and flank wear by employing combined techniques like Taguchi's Orthogonal array (OA) and statistical ANOVA associated with main effect plots in finish dry turning of hardened AISI 4340 steel (49 HRC) with $\mathrm{TiN} / \mathrm{TiCN} / \mathrm{Al}_{2} \mathrm{O}_{3} / \mathrm{TiN}$ multilayer coated carbide inserts. Additionally, surface topography of machined workpiece, wear mechanisms of worn coated carbide tool and chip morphology of generated chips are investigated using scanning electron microscope (SEM). The relationship between the responses and cutting parameters was established by regression analysis to formulate mathematical models. Finally, determine the tool life and analyze the economical feasibility of multilayer coated carbide inserts at their optimal parametric level in hard turning. This practical developments related to process improvement are very helpful and efficient from industrial point of view.

\section{Method}

To acquiesce the purpose of research work, cutting speed (v), feed (f) and depth of cut (d) have been chosen as cutting (process) parameters, while the responses are surface roughness, flank wear and chip morphology. The variable levels of the machining parameters have been selected within the intervals by taking account, the recommendations of manufacturer of the cutting tool (Taegutec Ltd.) and supported by previous work of various authors for investigating surface roughness, tool wear and chip morphology (Lima et al. 2005; Dogra et al. 2011; Sahoo \& Sahoo 2013; Shihab et al. 2014; Elmunafi et al. 2015; Panda et al. 2016). The identified factors and their associated levels are presented in Table 1. Using the selected factors (three) and factor levels (three), a

Table 1 Cutting parameters and their levels

\begin{tabular}{llllll}
\hline Parameters & Symbol & Unit & & \multicolumn{3}{l}{ Levels } \\
\cline { 4 - 6 } & & & 1 & 2 & 3 \\
\hline Cutting speed & $\mathrm{v}$ & $\mathrm{m} / \mathrm{min}$ & 100 & 160 & 220 \\
Feed & $\mathrm{f}$ & $\mathrm{mm} / \mathrm{rev}$ & 0.05 & 0.09 & 0.13 \\
Depth of cut & $\mathrm{d}$ & $\mathrm{mm}$ & 0.2 & 0.4 & 0.6 \\
\hline
\end{tabular}

design matrix was formulated in conformance with $\mathrm{L}_{9}\left(3^{3}\right)$ Taguchi's Orthogonal array design (Roy 1990). The experimental design matrix and results are showed in Table 2.

Dry longitudinal turning of round bar $(80 \mathrm{~mm}$ diameter and $100 \mathrm{~mm}$ length) of AISI 4340 high strength low alloy steel (HSLA) was performed using CNC lathe (SPRINT 16TC, Batliboi Ltd.) with $7.5 \mathrm{~kW}$ spindle power. The elemental composition of the workpiece material was determined by Spectro metal analyzer and the measured results are displayed in the Table 3. Before conducting experimental runs, the workpiece material was applied to heat treatment (quenching at $920^{\circ} \mathrm{C}$ and tempering at $400{ }^{\circ} \mathrm{C}$ ) to obtain an average hardness of $49 \mathrm{HRC}$, and later the exterior surface of the specimen was turned to remove the burr, oxide layers and other defaults. The cutting tool was used CVD multilayer (TiN/TiCN/ $/ \mathrm{Al}_{2} \mathrm{O}_{3} / \mathrm{TiN}$ ) coated carbide inserts (make: Taegutec Ltd.) having ISO designation CNMG120408 TT9235 were mounted on a tool holder PCLNL2525 M12 (Ceratizit make), which resulted in back rake angle $-6^{\circ}$, approach angle $95^{\circ}$, including angle $80^{\circ}$, clearance angle $6^{\circ}$ and nose radius $0.8 \mathrm{~mm}$. Surface roughness (Ra) was recorded using Surftest SJ-210 Mitotoyo roughness tester during each experiment. During the course of experimentation, the surface temperature of the machined samples were measured by the use of infrared thermometer (make: HTC MTX-2) having temperature range of $-30{ }^{\circ} \mathrm{C}$ to $550{ }^{\circ} \mathrm{C}$ and with optical resolution of $10: 1$. The flank wear (VB) of cutting tool was measured by optical microscope fitted with a digital camera and image analysis software. The measurement of chip thickness and the observation of chip shape are accomplished by collecting chip samples during experimental tests followed by measuring the average chip thickness with fifteen samples using digital vernier caliper. For extensive understanding of the cutting process, the quality of the hard turned surface, wear mechanisms of the worn cutting tool insert and chip morphology were observed by scanning electron microscope (EVO MA15, Carl Ziess SMT, Germany). The schematic representation of the experimental set up is depicted in Fig. 1. Surfaces with roughness average $(\mathrm{Ra})$ value in the range of $0.1-1.6 \mu \mathrm{m}$ are usually obtained by surface-finishing operation like grinding. The control limit for hard turning has been set as $1.6 \mu \mathrm{m}$. The standard tool life for the same is determined considering maximum flank wear width of $\mathrm{VB}=0.2-0.3 \mathrm{~mm}$ occurring at the tip of the tool or when the maximum value of Ra reaches $1.6 \mu \mathrm{m}$ which is similar to the surface finish attained by conventional grinding.

\section{Results and discussion} Surface roughness analysis

Analysis of the experimental results of surface roughness through Taguchi's OA experimental design are carried 
Table $\mathbf{2}$ Orthogonal array $L_{9}$ of Taguchi experiment design and experimental results

\begin{tabular}{|c|c|c|c|c|c|c|c|c|}
\hline \multirow[t]{2}{*}{ Run } & \multicolumn{3}{|c|}{ Coded values } & \multicolumn{3}{|c|}{ Actual setting } & \multicolumn{2}{|l|}{ Experimental results } \\
\hline & $\mathrm{v}$ & $f$ & $d$ & $v$ & $f$ & $d$ & Surface roughness (Ra) & Flank wear (VB) \\
\hline 1 & 1 & 1 & 1 & 100 & 0.05 & 0.2 & 0.994 & 0.05 \\
\hline 2 & 1 & 2 & 2 & 100 & 0.09 & 0.4 & 0.633 & 0.073 \\
\hline 3 & 1 & 3 & 3 & 100 & 0.13 & 0.6 & 0.916 & 0.105 \\
\hline 4 & 2 & 1 & 2 & 160 & 0.05 & 0.4 & 0.836 & 0.095 \\
\hline 5 & 2 & 2 & 3 & 160 & 0.09 & 0.6 & 0.574 & 0.124 \\
\hline 6 & 2 & 3 & 1 & 160 & 0.13 & 0.2 & 0.883 & 0.145 \\
\hline 7 & 3 & 1 & 3 & 220 & 0.05 & 0.6 & 0.698 & 0.185 \\
\hline 8 & 3 & 2 & 1 & 220 & 0.09 & 0.2 & 0.566 & 0.167 \\
\hline 9 & 3 & 3 & 2 & 220 & 0.13 & 0.4 & 0.776 & 0.225 \\
\hline
\end{tabular}

out with analysis of variance (ANOVA), where employed for determining the factor significantly influencing surface roughness $(\mathrm{Ra})$ is presented in Table 4. The ANOVA contains a table consisting of degrees of freedom (DF), sum of squares (SS), mean of squares (MS), F-values $(\mathrm{F})$, probability $(\mathrm{P})$ values and percentage of contributions. Statistical significance to surface roughness, $\mathrm{Ra}$ is evaluated by the P-values and F-values of ANOVA. The sources with P-value less than 0.1 (or $90 \%$ confidence) and with F-value larger than F-table are treated to have a statistically significant effect to the output response (Montgomery 2004; Mohanty et al. 2016a). The last column of the table presents the percent contribution of each source of the total variation and indicating the degree of influence on the surface roughness (Mohanty et al. 2016b).

Table 4 represents the results of ANOVA for average roughness (Ra). Out of the cutting parameters taken into account the effect of feed $(\mathrm{F}=42.81)$ is most significant on the output response surface roughness $(\mathrm{Ra})$, followed by cutting speed $(\mathrm{F}=13.37)$, as its $\mathrm{F}$ calculated value is more than $\mathrm{F}$ table value (9.0) and probability $(\mathrm{P})$ value is less than 0.1 at 90\% confidence level. This results is in concordance with those published in Bensouilah et al. (2016), Bouzid et al. (2014a), and Hessainia et al. (2013). The feed and cutting speed factors affect the surface roughness by $70.22 \%$ and $21.93 \%$ respectively. Although depth of cut does not present an important effect (insignificant), accounting $6.21 \%$ of total variability but it has decreasing control on Ra.

The main effect plot in Fig. 2 indicates that, the surface finish is eloquently improved by increasing cutting speed. It can be observed from Fig. 3 that the changing law of surface roughness is opposite to that of temperature within the machined surface, which means that increase of

Table 3 Chemical composition of AISI 4340 steel (wt\%)

\begin{tabular}{lllllllll}
\hline $\mathrm{C}$ & $\mathrm{Si}$ & $\mathrm{Mn}$ & $\mathrm{P}$ & $\mathrm{S}$ & $\mathrm{Cr}$ & $\mathrm{Mo}$ & $\mathrm{Ni}$ & $\mathrm{Fe}$ \\
\hline 0.384 & 0.231 & 0.613 & 0.025 & 0.028 & 1.007 & 0.230 & 1.418 & Balance \\
\hline
\end{tabular}

workpiece surface temperature indicates the quick improvement of surface finish. This is for the reason that with rise in cutting speed, the frictional energy and shear plane energy are optimal (Chinchanikar \& Choudhury 2015a) followed by culminated temperature at the shear plane and machined workpiece surface (see, Fig. 3), along with enhances the thermal softening of workpiece material and hence, forces needed for cutting decreases that causes an improved surface finish. This is in good agreement with Pal et al. (2014) when turning with hardened AISI 4340 steel. Another way; this decrease of surface roughness can be described by the reduced built-up-edge (BUE) formation, because of excess temperature produced in the chip-tool interface area as a function of raised cutting speed. When the built-upedge becomes unstable and large, it results improved surface finish. This study is analogous to the results obtained during hard turning of AISI 52100 steel with CBN tool (Khamel et al. 2012). The typical trend of curve in Fig. 2 represents gradual increase in feed enables surface roughness $(\mathrm{Ra})$ diminish prior to lowest value is achieved beyond which $\mathrm{Ra}$ again upsurges. With feed upto $0.09 \mathrm{~mm} / \mathrm{rev}$, surface finish improves due to fact that the uncut chip thickness becomes very small which might give rise to the ploughing (led to material side flow), instead cutting of material at lower feeds relative to higher feeds, as reported by Rech \& Moisan (2003) and Bartarya and Choudhury (2012). Nevertheless, more increase in feed, the contact length between the workpiece and the tool increases (Kaplan et al. 2014; Hessainia et al. 2015) and hence resulting in high thrust force (Nayak \& Sehgal 2015) since the cutting tool has to extract more volume of material from the workpiece (Das et al. 2016; Bouzid et al. (2014b); Aouici et al. 2014) thereby more vibration and heat generation (Basavarajappa et al. 2014) resulting in high Ra values. The experimental results show that average surface roughness are low at higher depth of cut but at a slower rate for which it can be considered as less affecting parameter 


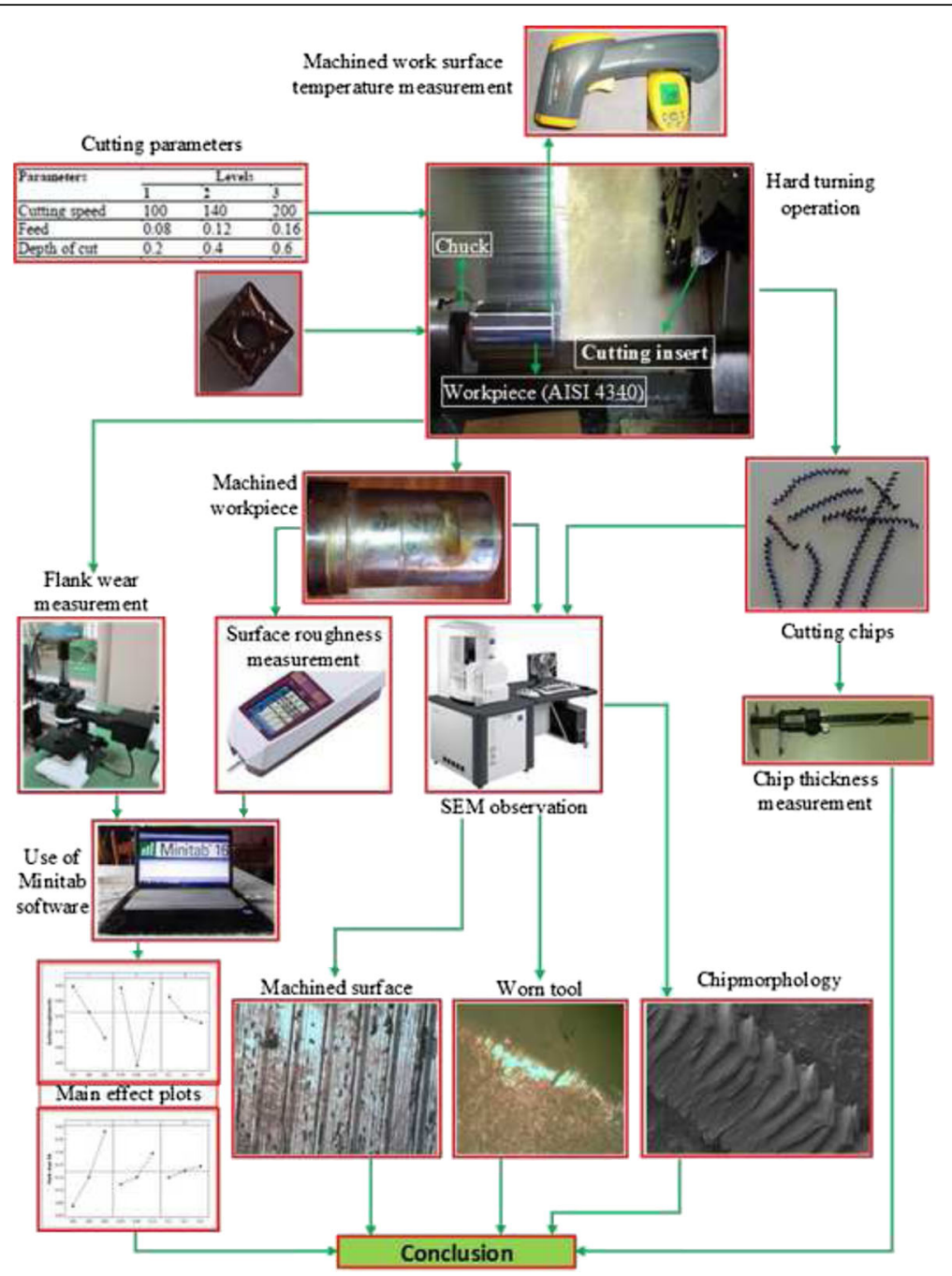

Fig. 1 The experimental setup. Figure 1 shows the schematic diagram of the experimental setup which deals with the equipment used for measurement of different performance characteristics, selected machine tool, cutting parameters, cutting tool material, statistical method for machinability investigation and scanning electron microscope for observation

for surface roughness in the studied range, which could be used to improve productivity if it would not worsen the surface microstructure. Similar observations are reported by Sahu et al. (2014).

Figure 4(a) and (b) displays the SEM images of the poor and best surface texture quality attained by the interaction between AISI 4340 hardened steel and multilayer (TiN/

Table 4 Analysis of variance for surface roughness (Ra)

\begin{tabular}{llllllll}
\hline Source & DOF & Seq SS & Adj SS & Adj MS & $F$ & $P$ value & C (\%) \\
\hline $\mathrm{V}$ & 2 & 0.042169 & 0.042169 & 0.021084 & 13.37 & 0.070 & 21.93 \\
$\mathrm{f}$ & 2 & 0.135049 & 0.135049 & 0.067524 & 42.81 & 0.023 & 70.22 \\
$\mathrm{~d}$ & 2 & 0.011942 & 0.011942 & 0.005971 & 3.79 & 0.209 & 6.21 \\
Error & 2 & 0.003155 & 0.003155 & 0.001577 & & & 1.64 \\
Total & 8 & 0.192314 & & & & & 100 \\
& & $S=0.0397157$ & R-Sq $=98.36 \%$ & R-Sq(adj) $=93.44 \%$ & \\
\hline
\end{tabular}

$\mathrm{TiCN} / \mathrm{Al}_{2} \mathrm{O}_{3} / \mathrm{TiN}$ ) coated carbide tool using various cutting conditions. From experimental observation, test number 1 $(\mathrm{v}=100 \mathrm{~m} / \mathrm{min}, \mathrm{f}=0.05 \mathrm{~mm} / \mathrm{rev}$ and $\mathrm{d}=0.2 \mathrm{~mm})$ and test number $8(\mathrm{v}=220 \mathrm{~m} / \mathrm{min}, \mathrm{f}=0.09 \mathrm{~mm} / \mathrm{rev}$ and $\mathrm{d}=0.2 \mathrm{~mm})$ support the evidence of these (poor and best) surface development. The SEM images show the status of machined surface in terms of surface voids, adhered oxides and chip particles, feed marks, material side flow, un-machined material, rough and smooth surface. The better surface finish due to increased cutting speed clearly noticed in Fig. 4. In Fig. 4(a), at lower feed $(0.05 \mathrm{~mm} / \mathrm{rev})$ feed marks become less apparent compared to a higher feed of $0.09 \mathrm{~mm} / \mathrm{rev}$ (see, Fig. 4(b)). For all turning tests, the measured Ra values were in the range of $0.566-0.994 \mu \mathrm{m}$, showing that coated carbide tool is effective to produce components with surface corresponding to those obtaining from grinding and other finishing operations. 


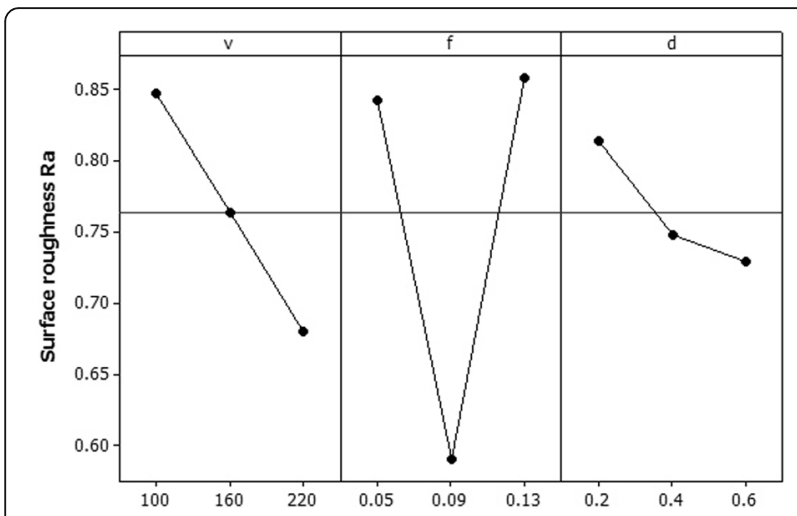

Fig. 2 Main effects plot for surface roughness (Ra). In the plots, the $x$-axis indicates the value of each cutting parameters $(v, f, d)$ at three level and $y$-axis the response value (here, surface roughness). Horizontal line indicates the mean value of the response. The main effects plots are used to determine the optimal design conditions to obtain the optimum value of surface finish. The main effect plot in Fig. 2 indicates that, the surface finish is eloquently improved by increasing cutting speed $(v)$ and depth of cut $(d)$

\section{Tool wear analysis}

Table 5 represents the results of ANOVA for flank wear (VB). ANOVA results revealed the amount of flank wear (VB) is greatly influenced by cutting speed, followed by feed and lastly by depth of cut. Similar observation was reported for flank wear in the previous published works of Dureja et al. (2010) and Boucha et al. (2014). Examination of P-value shows cutting speed and feed are the significant factors on flank wear (VB), which have contributed $81.93 \%$ and $15.23 \%$ respectively. The factor depth of cut does not present statistical significance on the obtained flank wear because of its smaller $F$

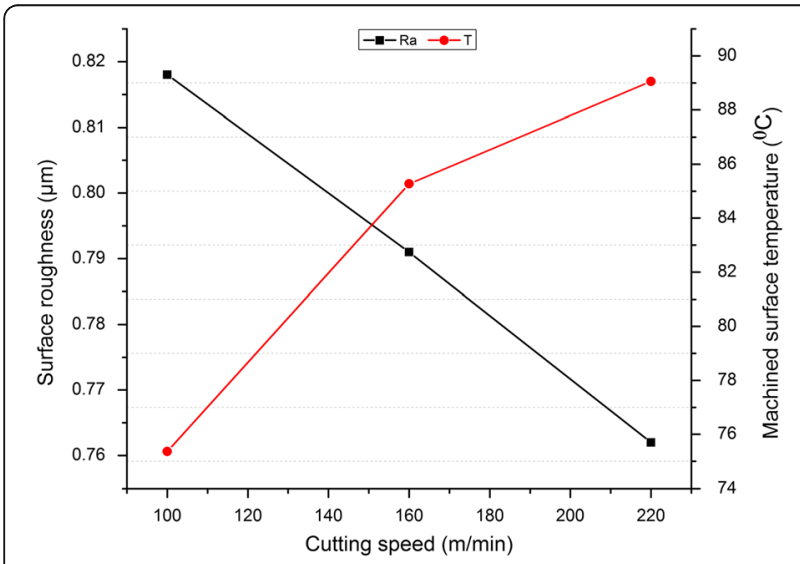

Fig. 3 Effect of cutting speed on surface roughness and machined surface temperature $(f=0.13 \mathrm{~mm} / \mathrm{rev}, \mathrm{d}=0.4 \mathrm{~mm}$ ). Figure 3 shows the variations of the surface roughness ( $R a)$ and machined workpiece surface temperature $(T)$ with cutting speed. This enhances the thermal softening of machined workpiece surface due to rise of temperature with speed and resulted in improved surface finish calculated value at $10 \%$ level of significance and accounting for only $1.81 \%$ of the total variability.

The main effect plots for tool flank wear (VB) in Fig. 5 indicates that flank wear increases with cutting speed and feed, resulting in abrasion marks (see, Fig. 6) due to sever rubbing effect between tool flank and machined surface by hard carbide in steels, broken-away particles from the cutting edge (Chinchanikar \& Choudhury 2015b). This behavior has received a number of explanations, including a higher degree of thermal softening in the chip formation zone due to lower thermal conductivity of outer layer (TiN) coating, and high abrasive nature of ultra-hard particles present in the workpiece material such as chromium-carbide $\left(\mathrm{Cr}_{7} \mathrm{C}_{3}\right)$, vanadiumcarbide (VC), molybdenum-carbide $\left(\mathrm{Mo}_{2} \mathrm{C}\right)$ and iron-carbide $\left(\mathrm{Fe}_{3} \mathrm{C}\right)$. Another way; the increase of flank wear can be explained due to the high concentration of the compressive stresses at the tool rake face close to the cutting edge as well as due to the expected high tool temperatures which leads to high cutting edge loads or reduced the hardness of tool due to thermal softening at the vicinity of cutting edge, reported by Horng et al. (2008).

Figure 7 emphasizes the impact of tool flank wear on surface roughness of machined part. While machining, for a flank wear (VB) of $0.121 \mathrm{~mm}$ attains the surface roughness (Ra) value $0.749 \mu \mathrm{m}$. Similarly, surface roughness (Ra) becomes $0.776 \mu \mathrm{m}$ (increase in 3.6\%) when the VB reaches $0.225 \mathrm{~mm}$, which clearly indicates the degradation of machined surface with the progress (increase) in flank wear. That means, the experimental study exhibits a close relation between flank wear and surface roughness. Similar findings are reported in the literature (Fnides et al. 2008; Bouchelaghem et al. 2010). However, surface roughness shows a gradual deterioration with increase in tool VB, surface roughness and tool wear does not exceed the control criterion of hard turning process (i.e. $\mathrm{Ra} \leq 1.6 \mu \mathrm{m}$ and $\mathrm{VB} \leq 0.3 \mathrm{~mm}$ ).

To derive the interaction, which governs tool wear and machined surface roughness, it is insightful to establish a coupled relation between Ra and VB. Although VB and Ra are connected with various machining parameters, it is acknowledged that one mutually affects the other then must obey an independent correlation. In addition, with regard to roughness (Ra)-wear (VB) curve (Fig. 7) a general mathematical model is proposed to develop correlation: $\mathrm{Ra}=\mathrm{K} \mathrm{e}^{\alpha \mathrm{VB}}$. The parameters $\mathrm{K}$ and $\alpha$ are coefficients that are 0.727 and 0.292 respectively. Equation (1) presents a model of surface roughness as a function of flank wear and vice-versa in a given cutting conditions.

$$
\mathrm{Ra}=0.727 \mathrm{e}^{0.292 \mathrm{VB}} \quad \mathrm{R}^{2}=87 \%
$$

\section{Chip morphology analysis}

Figure 8 confirms the formation of saw tooth type chip due to periodic crack propagation during of turning of hardened 

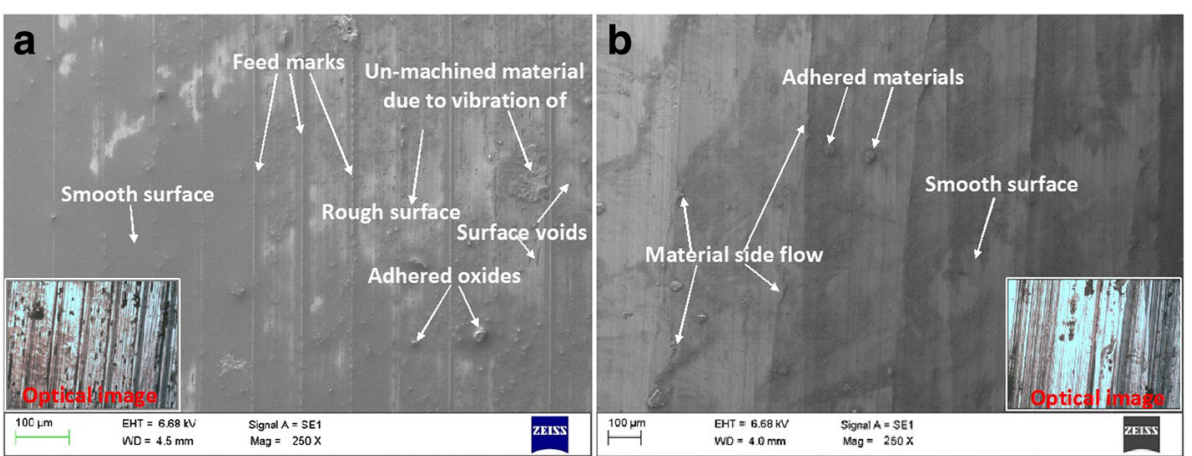

Fig. 4 SEM images of (a) poor and (b) best surface quality observed during turning of AISI 4340 steel. Figure 4 displays the SEM images of the poor and best surface texture quality attained by the interaction between AISI 4340 hardened steel and coated carbide tool using various cutting conditions. The SEM images show the status of machined surface in terms of surface voids, adhered oxides and chip particles, feed marks, material side flow, un-machined material, rough and smooth surface

AISI 4340 steel. In analyzing the chip morphology, it was noticed that severity of serration occurred in the free (top) surface of chip, including lateral flow and shear cracks could be attributed to plastic deformation of chips due to rise in temperature during machining. During hard turning process, high compressive stresses are experienced due to negative rake angles of the cutting tools (Dogra et al. 2010) which lead to the formation of cracks and plasticization due to the brittleness of the hardened steel, occurs at the chip's primary shear plane, resulting serrated chips. These cracks start on the chip's free surface and go deeper towards the tool nose, relieving the energy stored and acting as a sliding surface for the material segment (Konig et al. 1990). Simultaneously, heating and plastic deformation of the material occurs at the leading edge of the cutting tool. The process repeats itself in a cyclic manner after the chip segment has slipped with another new formation of crack and chip segment results in formation of saw-tooth chip (Sobiyi \& Sigalas 2015).

As the feed reduced and the cutting speed increased, a reduction of chip thickness is occurred (see, Fig. 9) and produced chips of three categories, i.e. long helical washer type broken chips, long and snarled unbroken chips and ribbon type chips. As reported by Tamizhamanii and Hasan (2012) this is due to large contact area on the rake face and small shear plane area at low cutting speed will result in thinner chips. In contrast, chip thickness increases with increase in feed because of the material ahead of the tool rake is under intense compressive stress state and hence large volume of material becomes fully plastic which results in thick chip, as reported by Neslusan et al. (2012).

\section{Correlation}

The relationship between the factors ( $v, f \& d)$ and the performance characteristics (Ra \& VB) were performed by multiple regression analysis. The following models were suggested:

$$
\begin{aligned}
\mathrm{Ra}= & 1.05-0.0014 * \text { cutting speed }+2.43 * \text { feed } \\
& -0.212 * \text { depth of cut }\left(\mathrm{R}^{2}=87 \%\right) \\
\mathrm{VB}= & -0.0969+0.000969 * \text { cutting speed }+0.604 \\
& * \text { feed }+0.0433 * \text { depth of cut }\left(\mathrm{R}^{2}=96 \%\right)
\end{aligned}
$$

The effectiveness of model has been performed by the help of $R^{2}$ value. When $R^{2}$ approaches to the value of unity, implying the response models have closely resembled the experimental data. In the present works, the $\mathrm{R}^{2}$ values for the surface roughness ( $\mathrm{Ra}$ ) and flank wear (VB) are $87 \%$ and $96 \%$ respectively, which reveals statistical significance of the model and the goodness fit for

\begin{tabular}{|c|c|c|c|c|c|c|c|}
\hline Source & DOF & Seq SS & Adj SS & Adj MS & $\mathrm{F}$ & $P$ value & C (\%) \\
\hline$v$ & 2 & 0.0206296 & 0.0206296 & 0.0103148 & 79.48 & 0.012 & 81.93 \\
\hline$f$ & 2 & 0.0038336 & 0.0038336 & 0.0019168 & 14.77 & 0.063 & 15.23 \\
\hline$d$ & 2 & 0.0004562 & 0.0004562 & 0.0002281 & 1.76 & 0.363 & 1.81 \\
\hline Error & 2 & 0.0002596 & 0.0002596 & 0.0001298 & & & 1.03 \\
\hline \multirow[t]{2}{*}{ Total } & 8 & 0.0251789 & & & & & 100 \\
\hline & \multicolumn{2}{|c|}{$S=0.011392$} & \multicolumn{2}{|c|}{$R-S q=98.97 \%$} & \multicolumn{2}{|c|}{$R-S q(a d j)=95.88 \%$} & \\
\hline
\end{tabular}
the model. Further, the diagnostic checking of the

Table 5 Analysis of variance for flank wear (VB) 


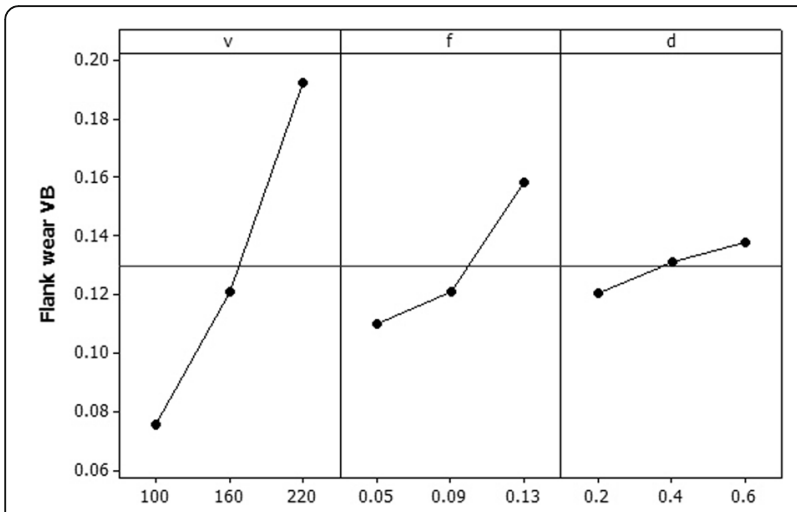

Fig. 5 Main effects plot for flank wear (VB). In the plots, the $x$-axis indicates the value of each cutting parameters $(v, f, d)$ at three level and $y$-axis the response value (here, flank wear). Horizontal line indicates the mean value of the response. The main effects plots are used to determine the optimal design conditions to obtain the optimum value of flank wear. The main effect plot in Fig. 5 indicates that, flank wear increases with cutting speed $(v)$, feed $(f)$ and depth of cut $(d)$

models were performed to prove its statistical validity. The Anderson-Darling test and normal probability plots of the residuals versus the predicted response for the surface roughness $(\mathrm{Ra})$ and flank wear $(\mathrm{VB})$ are plotted in Fig. 10. The residuals closely follow the straight line, which means there is a good agreement between predicted and experimental (actual) values. From Anderson-Darling test, the values of probability, i.e.,

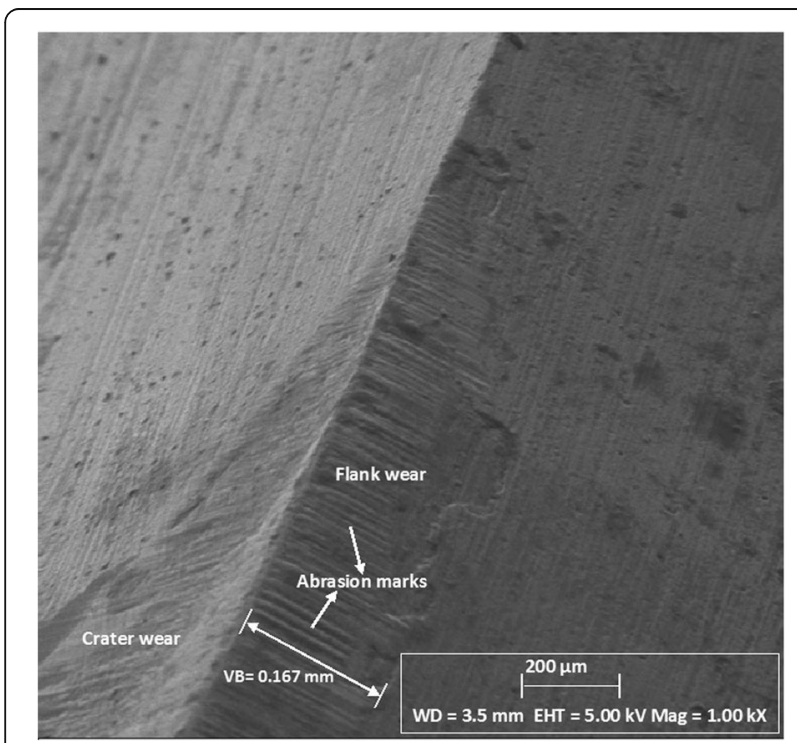

Fig. 6 SEM image of worn out coated carbide insert at $v=220 \mathrm{~m} / \mathrm{min}$, $f=0.09 \mathrm{~mm} / \mathrm{rev}$ and $d=0.2 \mathrm{~mm}$. Figure 6 shows an enlarged view of the tool wear of coated carbide tool at rake and flank face. The wear pattern on the flank indicates abrasive wear resulting from rubbing of the tool cutting edge and flank with workpiece material during cutting. The examination of the worn surfaces shows many abrasion marks and grooves on the flank surface

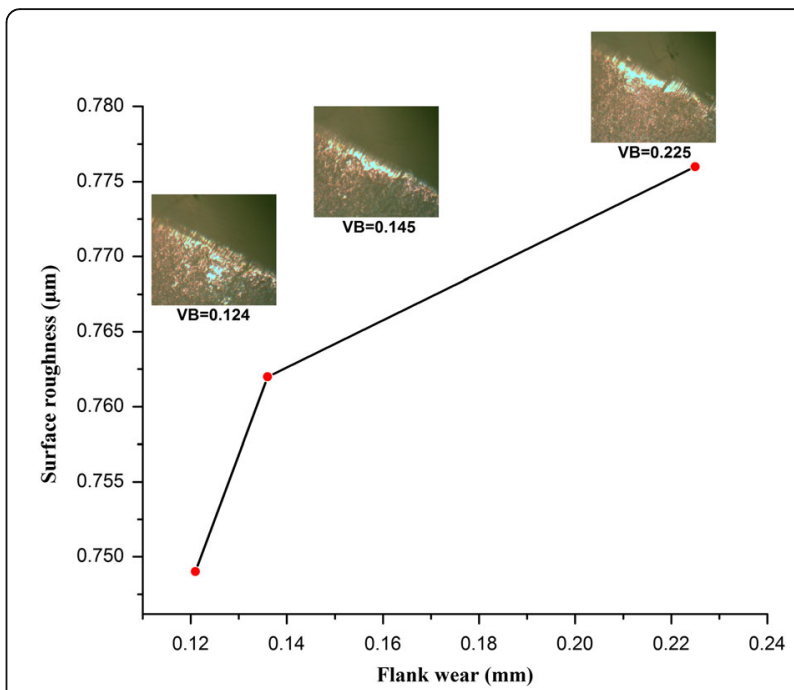

Fig. 7 Surface roughness vs. flank wear at $v=220 \mathrm{~m} / \mathrm{min} ; \mathrm{f}=0.13$ $\mathrm{mm} / \mathrm{rev} ; \mathrm{d}=0.4 \mathrm{~mm}$. Figure 7 illustrates the influence of flank wear on machined surface roughness, which showed that surface roughness is closely related and proportional to the flank wear. That means, any progress in flank wear indicates some degradation of the machined surface quality. Although it is taken that, as long as wear is usual and does not go beyond $0.3 \mathrm{~mm}$, surface roughness (exactly the criterion $\mathrm{Ra}$ ) increases gradually since Ra does not exceed the $1.6 \mu \mathrm{m}$

$P$-value (0.721 for $\mathrm{Ra}$ and 0.98 in case of VB) greater than alpha $(\alpha)$ of 0.05 (level of significance) confirms the normal distribution of data. It suggests developed models are adequate.

\section{Cost analysis}

Due to increasing demand of quality product at low cost and to replace cylindrical grinding, cost consciousness in

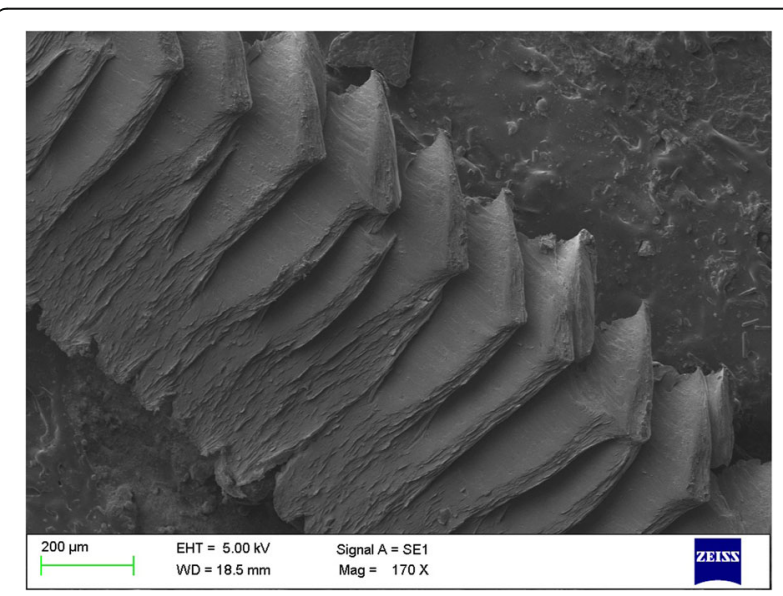

Fig. 8 SEM observation of chip morphology at $v=220 \mathrm{~m} / \mathrm{min}$, $\mathrm{f}=0.09 \mathrm{~mm} / \mathrm{rev}$ and $\mathrm{d}=0.2 \mathrm{~mm}$. Figure 8 shows the formation of saw tooth chip caused by sevier plastic deformation and oscillatory material flow at free (top) surface of the chip 


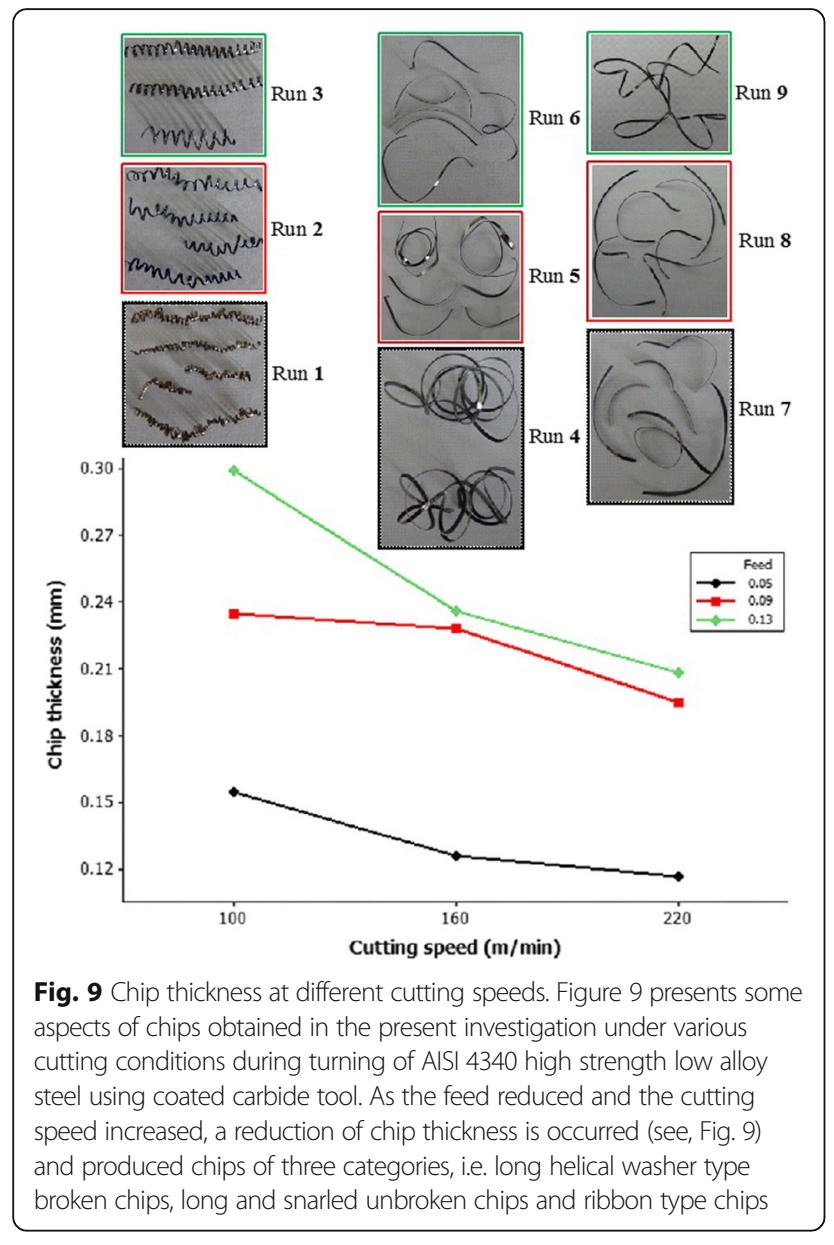

hard turning is an important aspect and crucial factor for an efficient manufacturing system. Generally, under optimized cutting conditions of process parameters, assessment of tool life judges the competence of machining process and reduction of machining cost. In hard turning, response surface optimization is mostly preferred for optimization of machining parameters. RSM optimization result for surface roughness (Ra) is shown in Fig. 11 and Table 6. The optimum cutting condition for surface roughness are in the region of cutting speed $(\mathrm{v})=220 \mathrm{~m} /$ $\min$, feed $(\mathrm{f})=0.087 \mathrm{~mm} / \mathrm{rev}$ and depth of cut $(\mathrm{d})=0.52$ $\mathrm{mm}$, which resulted the optimized surface roughness value $(\mathrm{Ra})$ of $0.447 \mu \mathrm{m}$. Finally, an experimental run was carried out under dry environment to evaluate the tool life at optimum cutting parameters (obtained by RSM technique) considering the criterion of surface roughness ( $\mathrm{Ra}$ ) rise above the value of $1.6 \mu \mathrm{m}$. The experimental results of flank wear and the growth of wear with respect to machining time have been shown in Fig. 12. In turning hardened AISI 4340 steel with multilayer $\mathrm{TiN} / \mathrm{TiCN} / \mathrm{Al}_{2} \mathrm{O}_{3} /$ TiN coated carbide insert, the tool life is observed about $39 \mathrm{~min}$ at optimum conditions. The estimation of cost (total machining cost per part) was performed using evaluated (39 $\mathrm{min}$ ) according to Gilbert's approach (Shaw 2005). From Table 7, it is found that approximate total machining cost per part using coated carbide inserts is $\$ 0.13$ (i.e. in Indian rupees Rs. 8.21). The multilayer coated carbide tools provides more savings than ceramic (Das et al. 2015) and CBN (More et al. 2006) tools and quite superior in reducing machining costs for finish hard turning applications.

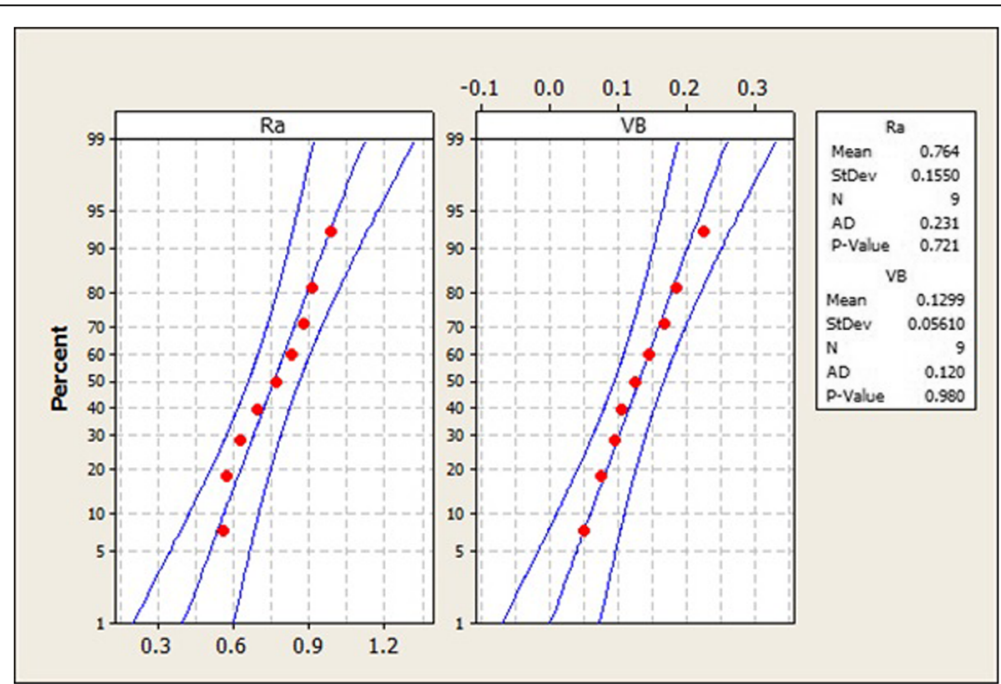

Fig. 10 Normal probability plot of surface roughness (Ra) and flank wear (VB). The graphs in Fig. 10 are Anderson-Darling test and normal probability plots of the residuals versus the predicted response for the surface roughness and flank wear. The measured points (red in colour) closely follow the fitted strait line. The Anderson-Darling test has good power and is especially effective at detecting departure from normality in the high and low values of a distribution. The null hypothesis is that the data distribution law is normal and the alternative hypothesis is that it is non-normal. Using the P-value which is greater than alpha of 0.05 (level of significance), so we cannot reject the null hypothesis (i.e., the data follow a normal distribution). Based on the plots and the normality tests, assume that the data are from a normally distributed population. This implies that the models proposed are adequate 


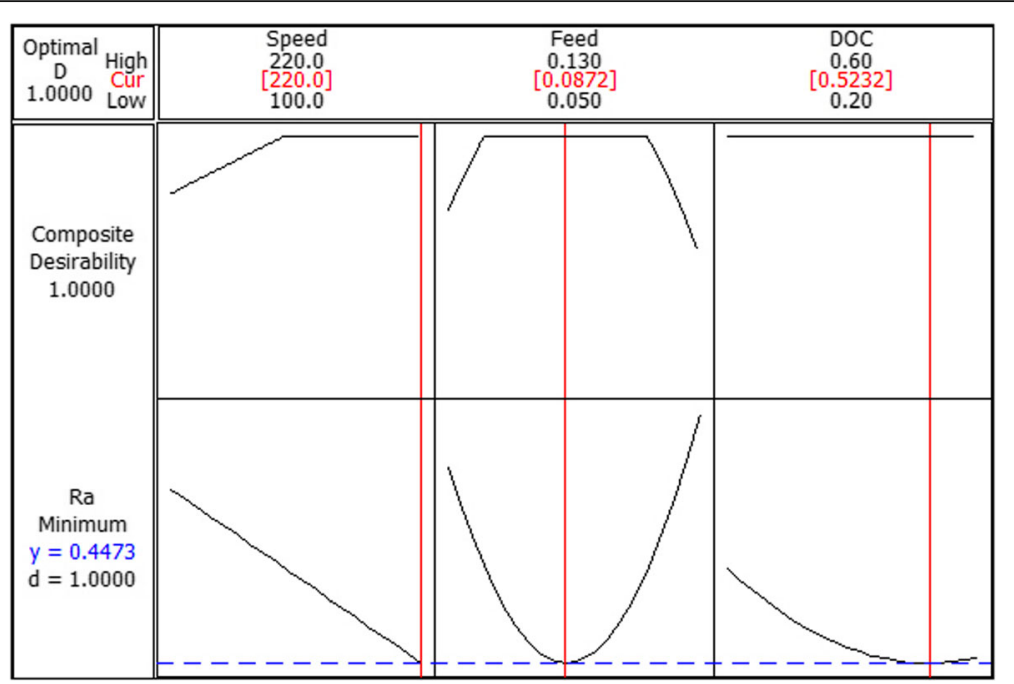

Fig. 11 Response optimization plot for surface roughness $(R a)$. The graphical optimization plot allows visual selection of the optimum machining conditions according to certain criterion. The result of the graphical optimization is the overlay plot. The following is the plot which describes the above explanation (Fig. 11)

\section{Conclusions}

Based on the experimental results and subsequent analysis, the following conclusions are drawn:

- ANOVA analysis indicates that feed becomes the most influential parameter for surface roughness (70.22\%) followed by cutting speed (21.93\%) and depth of cut (6.21\%). The surface roughness is continuously decreased with the increase in cutting speed, whereas surface finish improved with increasing feed (up to $0.09 \mathrm{~mm} / \mathrm{rev}$ ) and occurred a significant deterioration of surface finish with further increasing feed beyond the value of $0.09 \mathrm{~mm} / \mathrm{rev}$.

- Cutting speed exhibits the highest physical as well as statistical influence on the tool flank wear (81.93\%) followed by feed (15.23\%), whilst the depth of cut has a less effect (1.81\%). To minimize the flank wear, low level of all three parameters (v, f, d) should be performed.

- From SEM observation, abrasion was found to be the main wear mechanism of TiN/TiCN/ $/ \mathrm{Al}_{2} \mathrm{O}_{3} / \mathrm{TiN}$ multilayer coated carbide tool. From SEM micrograph, machined surface indicates feed marks, adhered oxides and chip particles, surface voids, material side flow, un-machined material, smooth and rough surface at the surface obtained best and poor surface finish in hard turning of AISI 4340 steel with coated carbide tool.

- Chip serration causes the formation of saw tooth chip due to cyclic crack at the free surface of the chip as a result of severe plastic deformation. With cutting parameters in the current study, increasing the cutting speed and decreasing the feed produced thinner chips (smaller chip thickness).

- During cutting of hardened AISI 4340 steel, the wear is one of the main factors to be considered, since it has a detrimental effect on surface quality of machined part. Despite the growth of flank wear (VB) is observed below $0.3 \mathrm{~mm}$, the surface roughness $(\mathrm{Ra})$ does not exceed the $1.6 \mu \mathrm{m}$ making the process comparable the grinding operation.

- Multiple linear regression models were developed for surface roughness and flank wear. The proposed models are adequate and statistically valid because of higher $R^{2}$ value $(0.87$ for $\mathrm{Ra}$ and 0.96 for $\mathrm{VB}$ ) and null hypothesis (P-value greater than 0.05; Anderson-darling test).

Table 6 Response optimization for surface roughness (Ra)

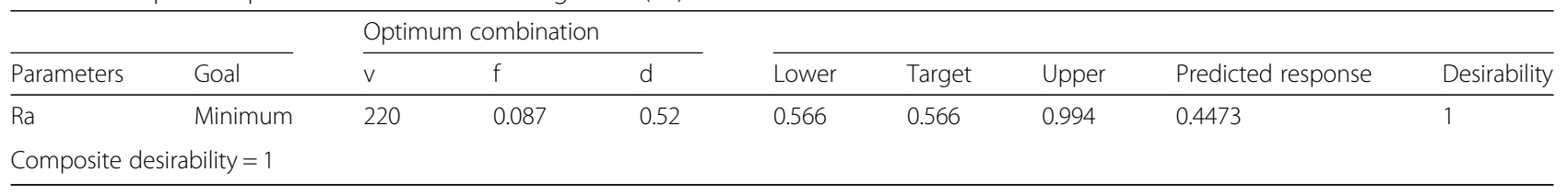




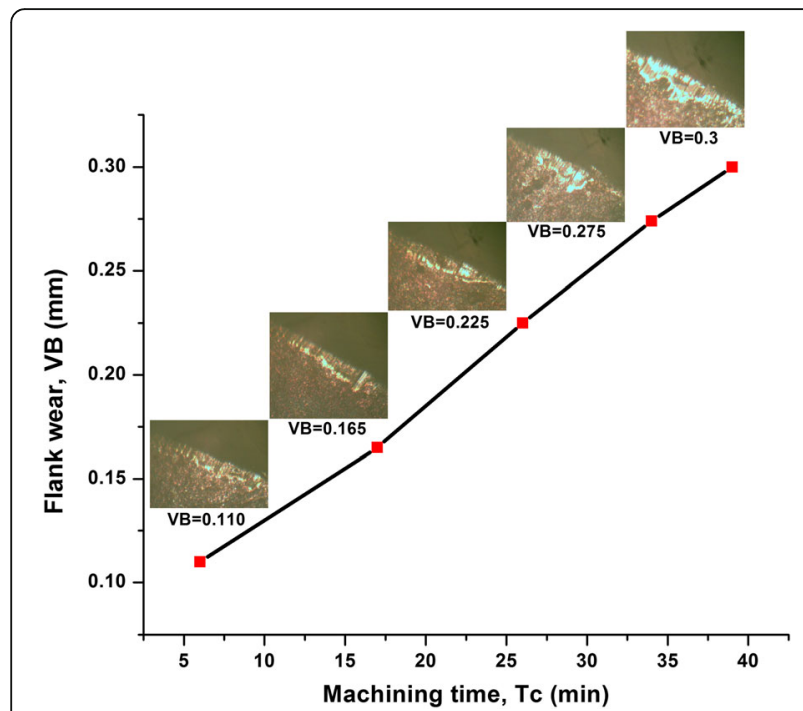

Fig. 12 Growth of flank wear vs. machining time at optimum conditions in hard turning. Figure 12 illustrates the growth of tool wear with machining time until the end of useful life of a tool as determined by flank wear width under optimum cutting conditions, considering wear criterion of VB up to $0.3 \mathrm{~mm}$

- It has been observed that the total machining cost per part using CVD multilayer TiN/TiCN/ $\mathrm{Al}_{2} \mathrm{O}_{3} /$ TiN coated carbide inserts is nearly $\$ 0.13$ (i.e. in Indian rupees Rs. 8.21) based on a single cutting edge under optimum cutting conditions $(\mathrm{v}=220 \mathrm{~m} / \mathrm{min}, \mathrm{f}=0.087 \mathrm{~mm} / \mathrm{rev}$ and $\mathrm{d}=0.52$ $\mathrm{mm}$ ) resulting higher tool life (39 $\mathrm{min})$, magnificent for hard turning applications.

- From the study, the effectiveness and potential of multilayer $\mathrm{TiN} / \mathrm{TiCN} / \mathrm{Al}_{2} \mathrm{O}_{3} / \mathrm{TiN}$ coated carbide tool for hard turning process during dry cutting condition possesses high yielding and costeffective benefit to substitute the traditional cylindrical grinding operation. Apart, it also

Table 7 Machining cost per part for coated carbide insert in hard turning

\begin{tabular}{lll}
\hline No. & Costs & Coated carbide \\
\hline 1 & Value of machine \& operator, \$3.2 per hour $(\mathrm{x})$ & $\$ 0.05 / \mathrm{min}$ \\
2 & Machining cost per part $\left(\mathrm{x} \mathrm{T}_{\mathrm{c}}\right)$ & $\$ 0.059$ \\
3 & Tool changing cost per part $\left[\mathrm{x} \mathrm{T}_{\mathrm{d}}(\mathrm{Tc} / \mathrm{T})\right]$ & $\$ 0.0076$ \\
4 & Tool insert cost per piece & $\$ 8$ \\
5 & Mean value of single cutting edge $(\mathrm{y})$ & $\$ 2$ \\
6 & Total cost per part $[\mathrm{y}(\mathrm{Tc} / \mathrm{T})]$ & $\$ 0.06$ \\
7 & Total machining cost per part $(\mathrm{C}),(2+3+6)$ & $\$ 0.13$ \\
\hline
\end{tabular}

Cutting conditions: cutting speed $(\mathrm{v})=220 \mathrm{~m} / \mathrm{min}$, feed $(\mathrm{f})=0.087 \mathrm{~mm} / \mathrm{rev}$, depth of cut $(\mathrm{d})=0.52 \mathrm{~mm}$, machining length $(\mathrm{L})=100 \mathrm{~mm}$, finished $\mathrm{w} / \mathrm{p}$ diameter $(D)=72 \mathrm{~mm}$, workpiece $=$ AISI $4340(49 \mathrm{HRC})$, flank wear $(\mathrm{VB})=0.3$ $\mathrm{mm}$, surface roughness $(\mathrm{Ra})=1.6 \mu \mathrm{m}$, machining time per part $\left(\mathrm{T}_{\mathrm{c}}\right)=\frac{\pi \mathrm{DL}}{1000 \mathrm{ft}}=$ $1.18 \mathrm{~min}$, machine downtime $\left(T_{d}\right)=5 \mathrm{~min}$, tool life for single edge $(T)=39 \mathrm{~min}$ contributes reasonable option to costlier $\mathrm{CBN}$ and ceramic tools.

\section{Abbreviations}

Adj MS: Adjusted mean of squares; Adj SS: Adjusted sum of squares; AISI: American Iron and Steel Institute; ANOVA: Analysis of variance; BUE: Build-up-edge; CBN: Cubic boron nitride; CCD: Central composite design; Cl: Confidence interval; CNC: Computerized numerical control; CVD: Chemical vapor deposition; d: Depth of cut $(\mathrm{mm})$; DOF: Degree of freedom; f: Feed (mm/rev); F: Variance ratio; HRC: Rockwell hardness; $\mathrm{N}$ : Number of experimental tests; $\eta_{\text {eff: }}$ Effective number of replications; OA: Orthogonal array; P: Statistical parameter; PVD: Physical vapor deposition; $R^{2}$ : Coefficient of determination; Ra: Average surface roughness $(\mu \mathrm{m})$; RSM: Response surface methodology; Seq SS: Sequential sum of squares; v: Cutting speed $(\mathrm{m} / \mathrm{min})$

\section{Acknowledgements}

The authors would like to thank Central Institute of Plastic Engineering and Technology, Bhubaneswar, India for providing their facilities to carry out the research work.

\section{Funding}

Not applicable.

\section{Availability of data and materials}

Not applicable.

\section{Authors' contributions}

Authors have made substantial contributions to conception, design, in the acquisition of data, and analysis and interpretation of data. Authors participated in drafting the article or revising it critically for important intellectual content. All authors read and approved the final manuscript.

\section{Competing interests}

The authors declare that they have no competing interests.

\section{Consent for publication}

Not applicable.

Ethics approval and consent to participate

Not applicable.

\section{Publisher's Note}

Springer Nature remains neutral with regard to jurisdictional claims in published maps and institutional affiliations.

\section{Author details}

'Department of Mechanical Engineering, JK Lakshmipat University, Jaipur 302026, Rajasthan, India. ${ }^{2}$ Department of Production Engineering, Veer Surendra Sai University of Technology, Burla 768018, Odisha, India.

Received: 28 November 2016 Accepted: 23 April 2017

Published online: 04 May 2017

\section{References}

Al-Ahmari AMA (2007) Predictive machinability models for a selected hard material in turning operations. J Mater Process Technol 190:305-311

Aneiro FM, Coelho RT, Brandão LC (2008) Turning hardened steel using coated carbide at high cutting speeds. J Braz Soc Mech Sci Eng 30:104-109

Aouici H, Yallese MA, Fnides B, Chaoui K, Mabrouki T (2011a) Modeling and optimization of hard turning of X38CrMoV5-1 steel with CBN tool: machining parameters effects on flank wear and surface roughness. J Mech Sci Technol 25:2843-2851

Aouici H, Bouchelaghem H, Yallese MA, Elbah M, Fnides B (2014) Machinability investigation in hard turning of AISI D3 cold work steel with ceramic tool using response surface methodology. Int J Adv Manuf Technol 73:1775-1788

Asiltürk I, Akkus H (2011) Determining the effect of cutting parameters on surface roughness in hard turning using the Taguchi method. Measurement 44: 1697-1704 
Asiltürk I, Çunkaş M (2011) Modeling and prediction of surface roughness in turning operations using artificial neural network and multiple regression method. Expert Syst Appl 38:5826-5832

Aslan E, Camuscu N, Bingoren B (2007) Design optimization of cutting parameters when turning hardened AISI $4140(63 \mathrm{HRC})$ with $\mathrm{Al}_{2} \mathrm{O}_{3}+\mathrm{TiCN}$ mixed ceramic tool. Mater Des 28:1618-1622

Bartarya G, Choudhury SK (2012) Effect of cutting parameters on cutting force and surface roughness during finish hard turning AISI52100 grade steel. Procedia CIRP 1:651-656

Basavarajappa S, Suresh R, Gaitonde VN, Samuel GL (2014) Analysis of cutting forces and surface roughness in hard turning of AISI 4340 using multilayer coated carbide tool. Int J Machining Machinability Mater 16:169-185

Bensouilah H, Aouici H, Meddour I, Yallese MA, Mabrouki T, Girardin F (2016) Performance of coated and uncoated mixed ceramic tools in hard turning process. Measurement 82:1-18

Bouacha K, Terrab A (2016) Hard turning behavior improvement using NSGA-II and PSO-NN hybrid model. Int J Adv Manuf Technol 86:3527-3546

Bouacha K, Yallese MA, Mabrouki T, Rigal JF (2010) Statistical analysis of surface roughness and cutting forces using response surface methodology in hard turning of AISI 52100 bearing steel with CBN tool. Int J Refract Met Hard Mat 28:349-361

Bouacha K, Yallese MA, Khamel S, Belhadi S (2014) Analysis and optimization of hard turning operation using cubic boron nitride tool. Int J Refract Met Hard Mater 45:160-178

Bouchelaghem H, Yallese MA, Mabrouki T, Amirat A, Rigal JF (2010) Experimental investigation and performance analyses of CBN insert in hard turning of cold work tool steel (D3). Machining Sci Technol 14:471-501

Bouzid I, Yallese MA, Belhadi S (2014a) RMS-based optimisation of surface roughness when turning AISI 420 stainless steel. Int J Mater Prod Technol 49:224-251

Bouzid L, Yallese MA, Chaoui K, Mabrouki T, Boulanouar L (2014b) Mathematical modeling for turning on AISI 420 stainless steel using surface response methodology. J Eng Manuf 229:45-51

Cakir MC, Ensarioglu C, Demirayak I (2009) Mathematical modeling of surface roughness for evaluating the effects of cutting parameters and coating material. J Mater Process Technol 209:102-109

Caydas U (2010) Machinability evaluation in hard turning of AISI 4340 steel with different cutting tools using statistical techniques. J Eng Manuf 224:1043-1055

Chinchanikar S, Choudhury SK (2013a) Effect of work material hardness and cutting parameters on performance of coated carbide tool when turning hardened steel: An optimization approach. Measurement 46:1572-1584

Chinchanikar S, Choudhury SK (2013b) Investigations on machinability aspects of hardened AISI 4340 steel at different levels of hardness using coated carbide tools. Int J Refract Met Hard Mater 38:124-133

Chinchanikar S, Choudhury SK (2015a) Machining of hardened steel-Experimental investigations, performance modeling and cooling techniques: a review. Int J Machine Tools Manuf 89:95-109

Chinchanikar S, Choudhury SK (2015b) Predictive modeling for flank wear progression of coated carbide tool in turning hardened steel under practical machining conditions. Int J Adv Manuf Technol 76:1185-1201

Das SR, Dhupal D, Kumar A (2015) Study of surface roughness and flank wear in hard turning of AISI 4140 steel with coated ceramic inserts. J Mech Sci Technol 29:4329-4340

Das A, Mukhopadhyay A, Patel SK, Biswal BB (2016) Comparative assessment on machinability aspects of AISI 4340 alloy steel using uncoated carbide and coated cermet inserts during hard turning. Arabian J Sci Eng 41:4531-4552

Davim JP, Figueira L (2007) Machinability evaluation in hard turning of cold work tool steel (D2) with ceramic tools using statistical techniques. Mater Des 28:1186-1191

Dogra M, Sharma VS, Sachdeva A, Suri NM, Dureja JS (2010) Tool wear, chip formation and workpiece surface issues in CBN hard turning: a review. Int J Precision Eng Manuf 11:341-358

Dogra M, Sharma VS, Sachdeva A, Suri NM (2011) Tool life and surface integrity issues in continuous and interrupted finish hard turning with coated carbide and CBN tools. J Eng Manuf 226:431-444

Dureja JS, Gupta VK, Sharma VS (2010) Design optimization of flank wear and surface roughness for CBN-TiN tools during dry hard turning of hot work die steel. Int J Machining Machinability Mater 7:129-147

Dureja JS, Singha R, Bhatti MS (2014) Optimizing flank wear and surface roughness during hard turning of AISI D3 steel by Taguchi and RSM methods. Prod Manuf Res 2:767-783

Elmunafi MHS, Yusof NM, Kurniawan D (2015) Effect of cutting speed and feed in turning hardened stainless steel using coated carbide cutting tool under minimum quantity lubrication using castor oil. Adv Mech Eng 7:1-7
Fnides B, Aouici H, Yallese MA (2008) Cutting forces and surface roughness in hard turning of hot work steel X38CrMoV5-1 using mixed ceramic. Mechanika 70:73-78

Gaitonde VN, Karnik SR, Figueira L, Davim JP (2009) Analysis of machinability during hard turning of cold work tool steel (Type: AISI D2). J Mater Process Technol 24:1373-1382

Hessainia Z, Belbah A, Yallese MA, Mabrouki T, Rigal JF (2013) On the prediction of surface roughness in the hard turning based on cutting parameters and tool vibrations. Measurement 46:1671-1681

Hessainia Z, Yallese MA, Bouzid L, Mabrouki T (2015) On the application of response surface methodology for predicting and optimizing surface roughness and cutting forces in hard turning by PVD coated insert. Int J Ind Eng Computations 6:267-284

Horng JT, Liu NM, Chiang KY (2008) Investigating the machinability evaluation of Hadfield steel in the hard turning with $\mathrm{Al}_{2} \mathrm{O}_{3} / \mathrm{TiC}$ mixed ceramic tool based on the response surface methodology. J Mater Process Technol 208:532-541

Hosseini A, Hussein HM, Kishawy HA (2016) On the machinability of die/mold D2 steel material. Int J Adv Manuf Technol 85:735-740

Kaplan Y, Okay S, Motorcu AR, Nalbant M (2014) Investigation of the effects of machining parameters on the thrust force and cutting torque in the drilling of AISI D2 and AISI D3 cold work tool steels. Indian J Eng Mater Sci 21:128-138

Khamel S, Ouelaa N, Bouacha K (2012) Analysis and prediction of tool wear, surface roughness and cutting forces in hard turning with CBN tool. J Mech Sci Technol 26:3605-3616

Konig W, Klinger M, Link R (1990) Machining hard materials with geometrically defined cutting edge - Field of applications and limitations. CIRP Ann Manuf Technol 39:61-64

Lalwani DI, Mehta NK, Jain PK (2008) Experimental investigations of cutting parameters influence on cutting forces and surface roughness in finish hard turning of MDN250 steel. J Mater Process Technol 206:167-179

Lima JG, Avila RF, Abrao AM, Faustino M, Davim JP (2005) Hard turning: AISI 4340 high strength low alloy steel and AISI D2 cold work tool steel. J Mater Process Technol 169:388-395

Meddour I, Yallese MA, Khattabi R, Elbah M, Boulanour L (2015) Investigating and modeling of cutting forces and surface roughness when hard turning of AISI 52100 steel with mixed ceramic tool: cutting conditions optimization. Int J Adv Manuf Technol 77:1387-1399

Mohanty CP, Mahapatra SS, Singh MR (2016a) A particle swarm approach for multi-objective optimization of electrical discharge machining process. J Intell Manuf 27(8):1171-1190

Mohanty CP, Mahapatra SS, Singh MR (2017) An intelligent approach to optimize the EDM process parameters using utility concept and QPSO algorithm. Eng Sci Technol 20:552-562

Montgomery DC (2004) Design and analysis of experiments, 6th edn. John Wiley $\&$ Sons, New York

More AS, Jiang W, Brown WD, Malshe AP (2006) Tool wear and machining performance of CBN-TiN coated carbide inserts and PCBN compact inserts in turning AISI 4340 hardened steel. J Mater Process Technol 180:253-262

Nabil K, Zahia H, Yallese MA, Ouelaa N (2012) Statistical analysis of surface roughness by design of experiments in hard turning. Mechanika 18:605-611

Nayak M, Sehgal R (2015) Effect of tool material properties and cutting conditions on machinability of AISI D6 steel during hard turning. Arabian J Sci Eng 40:1151-1164

Neslusan M, Sípek M, Mrazik J (2012) Analysis of chip formation during hard turning through acoustic emission. Mater Eng 19:1-11

Ozel T, Karpat Y, Figueira L, Davim JP (2007) Modelling of surface finish and tool flank wear in turning of AISI D2 steel with ceramic wiper inserts. J Mater Process Technol 189:192-198

Pal A, Choudhury SK, Chinchanikar S (2014) Machinability assessment through experimental investigation during hard and soft turning of hardened steel. Procedia Mater Sci 6:80-91

Panda A, Sahoo AK, Rout AK (2016) Investigations on surface quality characteristics with multi-response parametric optimization and correlations. Alex Eng J 55:1625-1633

Rech J, Moisan A (2003) Surface integrity in finish hard turning of case-hardened steels. Int J Machine Tools Manuf 43:543-550

Roy R (1990) A primer on the taguchi method, 2nd edn. SME, Dearborn

Sahoo AK, Sahoo B (2012) Experimental investigations on machinability aspects in finish hard turning of AISI 4340 steel using uncoated and multilayer coated carbide inserts. Measurement 45:2153-2165

Sahoo AK, Sahoo B (2013) Performance studies of multilayer hard surface coatings (TiN/TiCN/AI2O3/TiN) of indexable carbide inserts in hard 
machining: Part-II (RSM, grey relational and techno economical approach). Measurement 46:2868-2884

Sahu SK, Mishra PC, Orra K, Sahoo AK (2014) Performance assessment in hard turning of AISI 1015 steel under spray impingement cooling and dry environment. J Eng Manuf 229:251-265

Saini S, Ahuja IS, Sharma VS (2012) Influence of cutting parameters on tool wear and surface roughness in hard turning of AISI H11 tool steel using ceramic tools. Int J Precision Eng Manuf 13:1295-1302

Senthilkumar N, Tamizharasan T, Anandakrishnan V (2014) Experimental investigation and performance analysis of cemented carbide inserts of different geometries using Taguchi based grey relational analysis. Measurement 58:520-536

Shaw MC (2005) Metal cutting principles, 2nd edn. Oxford University Press, New York

Shihab SK, Khan ZA, Mohammad A, Siddiquee AN (2014) Optimization of surface integrity in dry hard turning using RSM. Sadhana 39:1035-1053

Sieben B, Wagner T, Biermann D (2010) Empirical modeling of hard turning of AISI 6150 steel using design and analysis of computer experiments. Prod Eng Res Dev 4:115-125

Singh D, Rao PV (2007) A surface roughness prediction model for hard turning process. Int J Adv Manuf Technol 32:1115-1124

Sobiyi K, Sigalas I (2015) Chip formation characterization and TEM investigation of worn PCBN tool during hard turning. Machining Sci Technol 19:479-498

Suresh R, Basavarajappa S (2014) Effect of process parameters on tool wear and surface roughness during turning of hardened steel with coated ceramic tool. Procedia Mater Sci 5:1450-1459

Suresh R, Basavarajappa S, Gaitonde VN, Samuel GL (2012) Machinability investigations on hardened AISI 4340 steel using coated carbide insert. Int J Refract Met Hard Mater 33:75-86

Tamizharasan T, Selvaraj T, Haq AN (2006) Analysis of tool wear and surface finish in hard turning. Int J Adv Manuf Technol 28:671-679

Thamizhmanii S, Hasan S (2012) Machinability study using chip thickness ratio on difficult to cut metals by CBN cutting tool. Key Eng Mater 504:1317-1322

\section{Submit your manuscript to a SpringerOpen ${ }^{\circ}$ journal and benefit from:}

- Convenient online submission

- Rigorous peer review

Immediate publication on acceptance

- Open access: articles freely available online

- High visibility within the field

- Retaining the copyright to your article

Submit your next manuscript at $\gg$ springeropen.com 